\title{
Wisdom-Based Economic Theory as Informed by Buddhism
}

OTTO CHANG

Paul E. Shaffer Professor of Accounting Emeritus

Purdue University Fort Wayne

ottobchang@gmail.com

Keywords: Buddhist economic model, production for profit, production for enlightenment, market economy

DOI: https://dx.doi.org/10.15239/hijbs.02.02.02

Abstract: This paper first identifies turbulent and imminent economic, social, and ecological problems threatening our modern economy and society. It is argued that many of these problems are natural or predictable consequences of the production-for-profit economic model feverishly advocated by mainstream economists and prevalently adopted by many policy makers in every corner of the world. The paper then examines the fallacy and deficiency of the production-for-profit economic model and its underlying philosophical tenets and premises. It shows that Buddhism, with its thorough examination of human predicaments and its pragmatic middle-way approach to the solution of these dilemmas, can be the philosophical basis for a viable alternative economic model which has not only the remedies for the problems created by the mainstream economic theories, but also the promise of a comprehensive solution to the human struggle for survival and prosperity. To help to formulate a new economic model, specific examples of how Buddhist principles can be applied to economic problems are elaborated and illustrated. The 
paper concludes with an urgent plea for the whole world to reconsider the efficacy of our current approach to economic well-being and to seriously consider the merits of a wisdom-based economic model as informed by Buddhism.

\section{Problems of Our Modern World}

I

$\mathrm{n}$ the last two centuries, rapid advance in technology and industrialization has drastically changed human history and the earth's landscape. Advances in technology brought forth innovation in production techniques and a mass quantity of new products and services to satisfy human desires. Industrialization and the use of capital equipment resulted in great efficiency in production, accumulation of personal wealth, and an increase in personal leisure which, in turn, stimulates an even greater demand for industrial products through intensified desire for consumption. Fueled by major breakthroughs in technology and know-how, industrial production and consumption of goods and services in the last century have grown exponentially and at an ever-increasing accelerated rate.

The ability of human beings to use technology to overcome limitations imposed by nature and to change nature in conformity with human expectations and desires have created a sentiment of optimism and self-confidence that was never found in the history of mankind. Equipped with this new-found faith in human capability and its sanctity, a new religion of mass consumption and production has become the sole dominating faith in human history. It is believed that an economic order based on human self-interest and free market competition represents the best approach to maximize individual utility as well as social welfare. Based on this philosophy, a capitalism-based free market economic model has become the dominating economic paradigm in both developed and developing countries worldwide. The modern world, boosted by mass production and consumption, has enjoyed a living standard that was inconceivable by people a hundred years ago.

The abundance of industrial goods and services, the improvement in transportation and communication infrastructures, the 
advance in medical care and public health, and the convenience of modern living, all undoubtedly represent considerable progress in human civilization. This does not necessarily imply that our modern world is without its problems or dilemmas despite the enthusiasm shared by many mainstream political economists on the robustness of our economy. On the contrary, our production-for-profit capitalist economic system has exhibited various signs of its inherently harmful effects on our economy, society, and ecology. The economy of scale and the increasing use of capital and technology have displaced many workers and created prolonged unemployment problems in many countries. The pursuit of profit, accumulation of capital, and concentration of wealth have led to greater and greater imbalance in income distribution within a nation and among nations. Self-interest and the laissez-faire nature of the market have induced many frauds and irregularities in capital and the labor market, as illustrated by the financial frauds such as Enron and WorldCom debacles. Increasing greed of investors and corporate managers has generated bubble economies characterized by exacerbated business cycles that add to economic and social instability. Emphasis on efficiency and economy of scale has facilitated the merger and formation of mega-multinational corporations that have monopoly power and significant political influences. Externalities of production costs encourage profit-seeking firms to pollute the air, water, and earth by transferring social costs to the society. Mass consumption and global industrialization have extensively depleted our natural and non-renewable energy resources. Indulgence in materialistic and sensual satisfaction has weakened modern people's morality and spirituality by depriving them of the opportunity to have long-lasting inner peace and happiness. Competition and economic injustice have incited alienation and hostility among citizens within a country and among nations. Urbanization and overcrowded cities have bred crime, traffic jams, air pollution, poverty and slums. Suicide rates in industrial countries are climbing. Ozone depletion and global warming have changed global weather patterns, agricultural outputs, and the entire earth ecology. Inequity in energy and resource consumption and imbalance in economic power and living standards have ignited conflicts and wars among 
nations. The following section illustrates that most of these problems are either directly induced by or indirectly related to the current economic model to which we subscribe and employ to guide our economic and social choices.

\section{Fallacy and Deficiency of Production-for-Profit Economic Model}

The production-for-profit economic model found in mainstream economic literature and college economics textbooks postulates that under the condition of perfect competition in a free market, if self-interested individuals or firms take actions to maximize their own gains or profits, the welfare of our society will also be maximized through increased efficiency in the allocation and use of our scarce resources and endowments. For the model to hold, the following assumptions are required:

1. Individuals in our society have unlimited and unabridged rights and freedom to obtain and possess properties and to pursue any economic activity.

2. All goods and services can be measured and expressed in monetary units, and there are markets or mechanisms of transactions in which these goods and services can be purchased and sold. This assumption further implies that:

a. All the property rights can be clearly defined and separated;

b. All the goods and services are private goods, no public goods are included;

c. No external benefits or external costs are involved.

3. The competition is perfect. It implies that:

a. Every participant has perfect information about the properties and utilities of goods or services that are exchanged;

b. There are so many buyers and sellers in the market that none of them can significantly influence the price and the quantity of the goods or services exchanged;

c. Each participant can freely enter or exit the market without any barrier or restriction. 
4. Utilities of individual persons or firms are maximized when the consumption of goods and services are maximized or when profit is maximized;

5. Social welfare is maximized when the utilities of individual persons or firms are maximized. That is, social welfare is a linear function of individual utilities.

6. Maximizing utilities in the current period will lead to maximization of utilities in the long term.

7. When natural resources are depleted, they can either be replenished or replaced by other alternative (maybe artificial) resources without impairing production capacity or living standards.

\section{II.1 Unrealistic Assumptions}

Several of these assumptions clearly do not describe reality. First, individuals in a society do not have unlimited and unabridged rights. If this were the case, our society would not have any laws or traffic rules. It is almost universally agreed that the welfare of the whole society should outweigh any individual 'natural right' claim. As an antidote to the authoritarian control exercised by organized religions before the Renaissance, we can understand why such declaration and emphasis of unlimited human right are necessary and needed. However, it is also a known fact that ordinary people are usually unenlightened to understand that society's interest should precede their own. Without a system of checks and balances, a society would just become so chaotic and dysfunctional that no individual would benefit from the society.

Second, many goods and services are not measurable in monetary units or exchangeable in a market. In fact, most non-material goods or services are difficult to price or trade in the market. For example, the cost and benefit of education are not usually measurable or determinable, as are those of religious services or services of national parks. The task of pricing these services is almost insurmountable. Moreover, many goods and services are, by their nature, public goods that can only be consumed collectively by the public. Examples are: air, the ocean, roads and parks, public safety, or national defense. For 
private goods, if the property rights can not be clearly defined, there will be benefits or costs accrued to external parties. In all these cases, the traditional market mechanism will not work as intended and there will be 'market failures'.

Third, information is not usually available to all the participants in the market. In fact, a considerable degree of information asymmetry exists among sellers and buyers in all markets. For example, in the product market, consumers usually have only limited knowledge about the nature of and risks associated with the product. In some industries, producers even intentionally hide certain key information from consumers. The most notorious are producers of tobacco and cigarette products, food and drug products, and sellers of used cars. For other household products, advertisements usually communicate partial or misleading information to the consumers. In the capital market, owners and management often use inside information to profit at the expense of third-party naïve investors. In the labor market, employees or agents' actions and efforts are usually not observable by employers or their principles. Consequently, they tend to serve their own interests rather than the employers' or owners' interests. The infamous CEOs who earn millions of dollars in compensation while the companies are losing large amount of money are good examples. The information asymmetry problem is so pervasive that enormous resources of our economy are spent on monitoring agents', employees', or producers' behavior and performance. In the economic literature, this is referred to as the 'agency' problem and the costs involved are called 'agency costs'.

Fourth, because of economy of scale or the existence of natural monopoly, many industries are dominated by a few producers. In the last fifty years, mergers and acquisitions became a key strategy for continuing growth in companies' sales and profits. Mega-size and cross-border corporations were created for this reason. These big corporations enjoy considerable influence in the price and outputs of their products and services. They also hold power to influence legislature and public policies through political contributions and political action campaigns. The utility crisis resulting from deregulation of the utility industry in the state of California was a perfect example. Manipulation of utility price by these corporations drove the cost of 
utilities so high that the State was close to bankruptcy and businesses were moving out of the state.

Fifth, consumption of goods or services is not the only contributing factor to individual utility or satisfaction. Although the assumption that more consumption is preferred to less consumption may be valid, there is a saturation point where individuals will not derive more satisfaction out of increased consumption. Modern psychology tells us that most sensory desires have a saturation point where more consumption may result in disutility or negative satisfaction to the individuals. This explains partially why people in highly developed urban areas are not necessarily happier than those who live under less fortunate conditions. In addition, we all know that human happiness is a complicated psychological phenomenon that depends on many physical, as well as mental factors. Materialistic consumption is one of the less relevant factors.

Lastly, maximizing individual utilities does not necessarily maximizing social utility if the output of goods and services is unevenly distributed. We all know that social welfare is a function of individual utilities, as well as the relative distribution of these utilities among society members. In other words, social utility may increase by redistributing the goods and services among its members even though the total outputs of goods and service do not increase. Generally, a more equitable distribution of goods and services among the members of the society usually increases the aggregate utility of the entire society.

The author has not discussed the fallacy of the remaining two assumptions because these assumptions are reserved for the next section where the deficiencies of the conventional economic model are elaborated upon.

\section{II.2 Deficiencies of the Model}

Note that by making several strong assumptions that greatly simplify the complicated economic problems confronted by us, the conventional economic model avoids several critical issues that should be further investigated and explored. In this subsection, some of these difficult issues are described and discussed below. 
What determines the utility of an individual or a society?

Is material consumption or satisfaction of sensory desires the only determinant of individual and social utility?

By assuming that the consumption of goods or service is the sole determinant in the utility function, the mainstream economic model ignores all other important determinants of individual and social utility. For example, from human psychology we learned that survival, physical comfort, and sensory gratification are at the bottom of human needs and wants. There are higher levels of human needs that tend to produce stronger and long-lasting satisfaction and happiness, e.g., self-actualization, a sense of belonging, love, harmony and peace. ${ }^{1}$ These aspirations and needs are universally and collectively accepted by all human beings, as evidenced by their presence in the literature of all cultures across all races and nations. If economics is a science that purportedly aims at the maximization of human utility or well-being, how can it afford to ignore these other important determinants of human utility or satisfaction? How can it afford to arbitrarily make such a simplistic and naïve assumption regarding human nature and human psychology? Admittedly, a good argument for the economists would be: this is the most workable and tractable model known to them at this moment. If this is the case, they should make it very clear how unrefined their model is. They should warn everyone about the risk of applying this model to economic planning and development and strive constantly to find a better model to deal with our economic problems. Most mainstream economists, however, are very complacent with this model and are very reluctant to step out of their traditional boundaries. They usually indicate that it is neither their expertise nor their responsibility to consider issues beyond the boundary of classical economics. Someone else, maybe the One from above with 'an invisible hand', will somehow automatically take care of the mess created by their model. The blind faith placed by the economists on the Almighty and their reliance on Him as part of the solution to human economic problems is indeed incredible by any religious standard. Classical eco-

1 Lyubomirsky, Happiness; Ash, 'Do Our Economic Choices', 11. 
nomics is, in fact, a religion that maybe more religious than religions traditionally practiced in human history.

\section{Can a social system based on the promotion of self-interest and competition increase the social well-being of mankind?}

The production-for-profit economic model relies primarily on human self-interest and competition to solve human problems. It asserts that if everyone behaves selfishly and competitively in an 'ideal' market where everyone is equal and none is a dominant player, the world will be 'magically' turned into an efficient factory where goods and services are produced for everyone's consumption. This theory is a myth itself. First, human endowment or talent is never equal. Second, the theory has a self-contradictory or self-defeating implication in practice. That is, if people are encouraged to practice selfishness and competitiveness as 'virtues', they eventually will do anything to get what they want, including breaking the law or exploiting each other. There is a constant incentive for them to play foul so that they can enjoy a relative advantage in a supposedly 'fair' game. This is consistent with the 'virtue' of being selfish and competitive. The prevalence of athletes' violation in using illegal drugs is a perfect example of this problem. The Enron and WorldCom debacles are real-life illustrations of the same problem in the economic arena. Undoubtedly, our economists will assert that our legal and professional code systems are effective in preventing most of these violations and irregularities. Here, conventional economists have again relied on something outside of their discipline to rescue their theory. They wishfully think that our legal system will work smoothly at an affordable cost. This is not something that their model should consider or deliberate; i.e., it is an exogenous variable for their model. In most cases, they simply assume that such enforcing mechanisms are given and cost nothing. In real-life, the direct costs involved in implementing our legal and enforcing infrastructure are considerable. Our whole democratic government system can be considered as one of the solutions to ensure the successful working of the classical economic theory. When such monitoring and enforcing mechanisms are weak or absent, a laissez-faire economic policy can only lead to chaotic and turbulent economic and social order. 
Furthermore, there are indirect social costs involved. Economic well-being is only one of the objectives for an ideal society. It is commonly agreed that a better society is characterized by certain humanistic values such as equality, cooperation, compassion, and peace. Here is the dilemma: To increase economic well-being, we need to promote selfishness and competitiveness; but to increase our social wellbeing, we need to promote selflessness and non-competition. Put differently, the achievement of our economic well-being is at the expense of our social well-being. This paradoxical situation is rather disheartening. As our economy becomes more developed, we have observed more social discord and problems. Imagine how much effort and resources would be needed for the rehabilitation of human integrity and human ideal after everyone is deeply programmed and conditioned by the dehumanizing process of economic development and growth! Our formal ethical education and informal religious practice today are no match to this Satanic giant with a towering ego and an insatiable desire to win and conquer.

\section{Does our natural endowment allow unlimited economic growth?}

Based on the assumption that the consumption of goods and services is the main source of human utilities, the capitalist economic model tends to overproduce. Given the philosophy that more is better, economic development is accelerated at a frantic pace in every corner of our planet earth. Unwavering optimism is present at every economic council or conference. Higher and higher economic growth rates are touted as evidence of effectiveness of governments and administrations at all levels. Nobody seems to care if more is necessarily better or if this unlimited pursuit in growth is achievable or maintainable. Implicit in this newfound faith is the belief that man can continuously deplete our natural resources and pollute our environment without endangering our ecology and our survival. Some cite the rapid advance in technology in the last fifty years as support to this faith that human beings can dictate their own destinies; that alternative resources will be found to replace the depleted resources; and that the earth ecology can be reformed to suit economic development and growth. Nothing could be more illusionary and elusive than claims like these. For those who would like to perform a reality 
check on the feasibility of unlimited economic growth, the arithmetic involved is very simple. Let's assume that the number of cars in the world grows by five percent a year, which seems to be a conservative estimate. At this growth rate, in less than twenty years the number of cars will be doubled. At the end of the next hundred years, the number of cars will be at least thirty-two times what we have today. Imagine then what kind of air pollution these many cars will produce! How much fossil oil is needed to run these cars! Of course, the optimists will say that by that time cars will be equipped with hydrogen engines rather than gas engines. Maybe so, but remember that the technology may not be economically feasible for quite a while and not everyone in the developing countries can afford a car with a hydrogen engine. Let us assume that approximately halfway through the technology becomes economically feasible. The pollution from these cars will still contribute a lot to the greenhouse effect! Today, the ozone depletion and the global warming effect have already changed the global weather pattern enough to cause thousands of deaths from heat waves in the city of Paris and numerous wild forest fires throughout the world. It does not require too much imagination to envision what this increased pollution will do to the mother earth.

Want another example? Worldwide energy consumption has increased very quickly because of global trade and economic development. Let us assume that global energy consumption grows at a conservative five percent a year. Again, the energy demand doubles in less than twenty years. How much fossil oils and natural gases should be burned to meet this increased demand? And how much pollution will be produced because of it? The examples are everywhere as depletions of many natural resources accelerate in many industries. The optimists may argue that man-made materials such as plastics will be discovered to substitute for the natural resources we need. But these artificial materials are not without risks and problems. Some of them are poisonous or harmful, and many of them are not biodegradable. Accumulation and disposal of this waste is a big headaches. As worldwide economic growth hastens, the costs we must pay for removing this waste will become astronomical. We can disagree on the estimates of all these numbers and how quickly our natural resources will be depleted. But one thing is very clear. Our natural resources and endow- 
ment will not support unlimited production of goods and services to support the ever-increasing consumption encouraged by the classical economics. The enormous external social costs and the increasing damage to our ecology will offset any economic progress we make. In other words, current economic growth will not be sustainable if nothing is changed in our approach to worldwide economic development. Continuous economic growth following the current capitalist path is at best a false promise, if not a pure fantasy or a total disaster.

\section{Can markets distribute income fairly to ensure social equality and harmony?}

A perfectly competitive market does not require that each participant in the market have the same endowment. But the assumption that there are many players in the market and none of them have significant influence implies that equal endowment of market players is preferable for the market economy to work efficiently. In real life people are endowed with unequal wealth and talents. In a capitalist society, there is no mechanism in the model to redistribute income fairly and equally. Consequently, the rich will become even richer, and the poor even poorer. Without external intervention, such as progressive income taxes or government subsidies, the disparity between the rich and poor will become larger and larger. A good example can be found in the U.S. economy. During the last two decades, U.S. federal taxation sharply turned regressive. Empirical data in the period show that income disparity has been widened.

\section{Does maximization of current utility necessarily lead to maximization of long-term utility?}

In the production-for-profit economic model, inter-generational equity is totally ignored. The assumption is that what is good for this generation is also good for future generations. Current production only needs to satisfy the utility of today's consumers. It is perfectly all right to deplete natural resources and to pollute our environment to satisfy current demand. Whether today's consumption will negatively impact tomorrow's consumption is an issue seldom addressed in the classical economic model. Profit is a short-term measure of success. It is usually calculated on a yearly basis. Such short-term em- 
phasis will necessarily induce overproduction in current periods and underproduction in the future periods given our limited natural resources. Proponents of the market model usually argue that advances of technology in the future will create substitutes for natural resources and thereby reduce the problem to a manageable level. Such blind faith in technology and in its capability to replenish our natural capital may be too optimistic to the extent of being unreasonably imprudent or irrationally irresponsible.

\section{Can the market economy facilitate full employment if it is socially desirable?}

In the market economy, labor is considered just like a commodity and subject to the same rules of demand and supply in the labor market. If demand for consumption goods rises (or decreases), the derived demand for labor as an input in the production process will also rise (or decrease). As an economy goes through the boom and doom of a business cycle, labor employment (or unemployment) will also fluctuate. Unemployment, therefore, is a natural consequence of the market mechanism. It is not only unavoidable but also acceptable. For many people who are socially conscientious, however, unemployment is considered as an indication of social injustice and thus highly undesirable. It imposes a heavy cost to the unemployed individuals, as well as to the society. The unemployed may have to live at the poverty level, losing health benefits, homes, and self-respect and self-confidence. Marriage and the family will also suffer and may break up. In areas where the unemployment rate is high, crime, drugs, and social unrest are common. This is the reason why governments usually intervene by establishing unemployment insurance programs and increasing government spending to create more jobs. As technology advances, more and more jobs will be displaced by machines and computers. The increasing global trade will also cause more jobs to be transferred to foreign countries where labor cost is lower. Unemployment seems to be a perennial problem that can not be easily avoided in a capitalist economy guided by classical economic theory. 


\section{II.3 The Need for an Alternative Approach}

Economics, as a study of human behavior, cannot avoid value judgments. Struggle as it may, economics as a discipline is never free from ideology. ${ }^{2}$ The content and application of economic reasoning are determined ultimately by the force of what economists believe, not by an independent and neutral logic. ${ }^{3}$ Modern capitalist economic thought can trace its origins to Adam Smith. The philosophical basis of Smith's argument rested on his beliefs that (1) all men had the natural right to obtain and protect their property; (2) all men were by natural, materialistic; and (3) all men were rational and would seek, by their own reason to maximize their material well-being. While this body of thought has been built upon and modified over the past two hundred years, the influence of Adam Smith is evident in every conventional economics textbook. Common sense tells us, however, that a lot has changed since Smith's day. Today, business is big. There are labor unions and big government to interfere with his balanced free market of equals. His optimistic view of a naturally growing and expanding system is now replaced by growth problems and by a steady dose of pessimism in most glances toward the future. ${ }^{4}$ The unlimited promotion of self-interest and unchecked consumption of material goods have shaped a post-industrial world characterized by greed and fraud in the markets, sex and violence in our culture, PAC and special interest in our government, secularization and intolerance in our religion, alienation and hatred in our society, turbulence and turmoil in our economy, and pollution and destruction to our environment.

As discussed and analyzed in this section, many assumptions inherent in the capitalist economic models are either non-descriptive of reality or too simplistic to adequately address the whole spectrum of macroeconomic and social issues. Keynes somewhat foresaw all these:

\footnotetext{
2 Carson, Economic Issues, 9.

3 Carson, 10.

4 Carson, 13
} 
It is not true that individuals possess a prescriptive 'natural liberty' in their economic activities. There is no 'compact' conferring perpetual rights on those who have or on those who acquire. The world is not so governed from above that private and social interest always coincides. It is not a correct deduction from the Principles of Economics that enlightened self-interest always operates in the public interest. Nor is it true that self-interest generally is enlightened, more often individuals acting separately to promote their own ends are too ignorant or too weak to attain even these. ${ }^{5}$

Robert Heibroner has long argued that capitalism as the self-regulating system analyzed in conventional economic theory simply does not exist. He contended that 'the persistent breakdowns of the capitalist economy, whatever their immediate precipitating factors, can all be traced to a single underlying cause. This is the anarchic or plan-less character of capitalist production'. ${ }^{6}$ Conventional economic model and its underlying philosophical thoughts, if carefully examined and analyzed, resemble unverifiable belief systems or religion rather than coherent science inquiries. Nelson observed that:

conventional economics is not entirely based on a rational (scientific) foundation nor proven by analysis. Many underlying premises of classical economics are quasi-ethical statements and contain value judgments akin to religious studies. Neoclassical economics has supplanted religion in providing promises of the true path to salvation in this world?

In the neoclassical theory, individual utility maximization drives everything, and good and evil are simply seen as efficiency and inefficiency in production. God is replaced by the search for individual gain. After carefully analyzing the inadequacy of the neoclassical economics in delivering the salvation it promised, Nelson concluded that:

\footnotetext{
5 Keynes, End of Laissez Faire, 68.

6 Heilbroner, Limits, 88.

7 Nelson, Economics, 20. Emphasis is my own.
} 
If the members of the American economics profession do not move to incorporate cultural elements, including religion, more directly into their thinking, they may simply have to concede that professional economics is unable to say anything of importance concerning some of the most vital determinants of the efficiency and other outcomes of economic systems... The old ideas and institutions that provided us with faith in the benefits of economic progress as the salvation of our world no longer holds, a rethinking of the way we approach our social and economic questions is recommended. ${ }^{8}$

If the classical economic model is a false 'religion' that has problems delivering its promise of salvation, maybe we should look at traditional religions for inspiration and guidance. Oslington sees this possibility when he argues that theology should not be separated from economics. ${ }^{9}$ He believes that theology can provide a framework for ethics that economics seems to be searching for as part of the current revival of interest in the relationship between ethics and economics represented by works such as Hausman and McPherson's Economics and Moral, Groenewegen's Economics and Ethics, and Gardner's Inspiring Progress. Attempts to seek guidance from religions for alternative approaches to our economic problems go back a long way in human history. More recently, Schumacher noted that 'Right Livelihood is one of the requirements of the Buddha's Noble Eightfold Path. It is clear, therefore, that there must be such a thing as a Buddhist economics'. ${ }^{10}$ Schumacher's work on Buddhist Economics was followed by authors such as N. Takatsugu, F. L. Pryor, and G. Alexandrin, S. Zadek, P. Payutto, H. NorbergHodge, A. Puntasen, P. Daniels, T. A. Golden, L. Zsolnai, F. Rotering, and C. Brown. ${ }^{11}$ Other authors have examined the implication of other religions on economics; for example, C. A. Kent and A. Henley

\footnotetext{
8 Nelson, Economics, 262.

9 Oslington, Theological Economics, 32.

10 Schumacher, Small is Beautiful, 50.

11 Takatsugu, 'The Influence of Confucianism', 53; Pryor, 'A Buddhist Economic System', 17; Alexandrin, 'Elements of Buddhist Economics', 3; Zadek,
} 
on Christian Economics, ${ }^{12}$ M. A. Choudhury and M. A. Khan on Islamic Economics, ${ }^{13} \mathrm{M}$. V. Rosser et al. on neo-Confucian economics; ${ }^{14}$ and G. Alexandrin and C. Zech, and R. Wilson on comparative religions and economics. ${ }^{15}$ In the following section, the author outlines what he believes Buddhism can contribute toward the construction of a viable alternative economic model.

\section{Buddhist Approach to Economics}

\section{III.1 Buddhist Premises}

Buddhism is a system of philosophical beliefs and reasoning with the purpose of achieving the highest well-being and total relief of suffering for all sentient beings. The whole system of practices is based upon a clear understanding of reality, self-discipline, and compassion. Its basic premises include the following:

1. Achievement of highest well-being and relief from all suffering (salvation) can only be attained through an individual's enlightenment-complete understanding and total acceptance of reality and its laws of causes and effects without attachment to one's ego, misconception, delusion, fancies,

'The Practice of Buddhist Economics', 433; Payutto, Buddhist Economics and Buddhism and The Business World; Norberg-Hodge, 'Buddhism in the Global Economy', 15; Puntasen, Buddhist Economics; Puntasen, 'Buddhist Economics', 181; Daniels, 'Economic System', 245; Daniels, 'Buddhism and the Transformation', 155; Golden, 'The Relevance of Buddhist Economics'; Zsolnai, Ethical Principles; Rotering, Contractionary Revolution; Brown, Buddhist Economics.

12 Kent, 'A Christian Approach', 80; Henley, 'Economic Orthodoxy', 56.

13 Choudhury, 'Islamic Economics', 35; Khan, 'The Future of Islamic Economics', 248.

14 Rosser et al., 'The New Traditional Economics', 763.

15 Alexandrin and Zech, 'Ancient Futures', 1344; Wilson, Economics, Ethics, and Religion. 
desires, preferences, and unachievable goals. Enlightenment, therefore, relies exclusively on human rationality and self-discipline. It's not by grace of the Divinity, nor can any supernatural power come to aid. Enlightenment can only be accomplished through a carefully planned training to eradicate ignorance, eliminate logical leaps and inconsistencies, enhance mindfulness, and continually self-diagnose and improve.

2. A great deal of individual suffering and human misery are mostly caused by ignorance, delusion and emotional disturbance rather than lack of material possessions or holdings. In fact, Buddhists are warned that pursuit of excessive material possessions and sensatory gratification often leads to the vicious cycle of dependence and anxiety, the cycle of never-ending suffering or 'samsara'. Individual utility is therefore defined in terms of a balanced portfolio of physical maintenance and comfort, sensatory gratification, emotional tranquility, and, most importantly, spiritual transcendence.

3. Everything in our world is interrelated, interdependent, inter-penetrating, and inter-possessive through an enormous network of links and relationships between causes and conditions. An individual's wellbeing or utility is so intertwined with other sentient beings' welfare and utility that separation of them is infeasible and undesirable. In fact, individual achievement of enlightenment or highest wellbeing is impossible without simultaneous achievement of highest well-being by other sentient beings. Given this belief, utility of a society is therefore measured by equality, freedom, democracy, peace, respect for each other and nature, love and kindness, and an institutional structure to facilitate all individuals to reach enlightenment.

4. Things constantly change as their dependent conditions and causes change. Nothing can exist independently and eternally. No ideology or modeling can be applied to reality without necessary adjustments as causes and conditions change. 
Extreme 'isms' and dogmas should be avoided because or their false claim of universal validity. This is referred to as the 'Middle Way' approach in Buddhism. The Middle Way approach requires a practitioner to take a pragmatic, realistic, adaptive, experimental, and innovative attitude to life's problems. By doing so, a practitioner would not fall into the trap of dogmatism, absolutism, and other forms of prejudice and fallacy. He is always mindful and self-monitoring, taking the rightful action to ensure a dynamic equilibrium and balance. More importantly, he would not impose a uniform goal for everyone or insist on a single approach to each problem. He would allow individuals the freedom to select their own approach commensurate with their different predispositions and circumstances. Through the concept of 'Upaya' and the use of 'skillful means', a Buddhist society is always pluralistic, democratic, and authentic. Although a Buddhist society allows and respects diversity, it would not create division, discordance, or fragmentation. In the pursuit of ultimate enlightenment, all individual and social efforts are integrated and coordinated under a unified goal of reaching the highest wellbeing for all sentient beings. Buddhism is therefore both pluralism and universalism. It is 'integralism' or 'oneness'. It is the 'Middle Way'.

\section{III.2 Buddhist Responses to Economic Questions}

How could Buddhist beliefs and premises be applied to guide our search for an alternative economic model? A comprehensive economic model needs to address the whole spectrum of the ethical, social, and economic issues involved in the pursuit of the highest human wellbeing. Example of these issues would include:

1. What do people want? Answers to this question will require the definition and specification of individual utility functions.

2. What do people need to have to achieve what they want? Answers to this question would require the definition and 
specification of basic economic needs, desired consumption bundles, and choices of work, leisure and lifestyle.

3. How can we produce to provide what people need? Answers to this question would require specification of the modes and social relations of production, scale of production, use of technology and its impact on the nature and ecology.

4. What quantity needs to be produced and at what price? Answers to this question would require specification of exchange relations, market structure and its failure or limitations, and feasibility and efficiency of economic planning.

5. How should our society be organized to maximize social welfare? Answers to this question would require the specifications of social priorities, the legal and political structure, and government regulations required.

The author will describe below how a Buddhist might answer these questions. The attempt is to show that Buddhism, though designed originally for a soteriological purpose, is quite amendable to mundane worldly matters. In fact, Buddhism is far more direct than classical economics in addressing the human satisfaction problem. Schumacher made the following observation:

Buddhist Economics is the systematic study of how to attain given ends with minimizing means. Modern economics, on the other hand, considers consumption to be the sole end and purpose of all economic activities, taking the factors of production-land, labor, and capital. The former, in short, tries to maximize buman satisfactions by the optimal pattern of consumption, while the latter tries to maximize consumption by the optimal pattern of productive efforts. ${ }^{16}$

The inadequacy of the classical economics is rather obvious. It

\footnotetext{
16 Schumacher, Small is Beautiful. Emphasis and abridged by author.
} 
addresses the wrong problem based upon a simplified assumption. Maximization of consumption does not necessarily lead to maximization of human satisfaction. ${ }^{17}$ The sweeping neoclassical assumption simplifies the complexity of human desires, motives and welfare into the quest for material accumulation. This is necessary for statistical analysis, but it gives a false sense of objectivity by ignoring that materialistic consumption is simply one variant of a set of dynamic and highly differentiated ethical motives - all of which have an important influence on the means and ends of the production system. ${ }^{18}$

\section{Human Satisfaction and Efficient Consumption}

For a Buddhist, the highest human satisfaction comes from complete enlightenment. When enlightenment is realized, a practitioner is free from all suffering and afflictions. The external hustle and bustle hardly affects their peaceful mind. Bliss and exquisite joy come exclusively from within. Through long periods of rigorous practice, they have attained the ability of concentration and calm-abiding. Internal tranquility and a fluid mindset bring forth a constant flow of joy and happiness. They feel that nothing is lacking, that their life is full, and that they are the richest person in the world. They literally own the whole world because they appreciate everything in the word. In fact, the world is them and they are the world. Through diligent training, they have torn down the boundary of self and transcended the duality of the subject and the object. They have become the most efficient consumer of all because they reach the highest human satisfaction with minimal consumption of resources. In contrast, an ordinary person is always grasping for some thing, whether it is money, fame, companionship, or some fantasies, the more the better, and the pursuit keeps on going on and on. Strangely, however, the more one accumulates, the less happiness and enjoyment they can derive from their possessions. They are becoming less and less efficient as a consumer. This nature of human being is even recognized in the traditional economic literature as the law of diminishing marginal

17 Pathompituknukoon and Suriya, 'Mathematical Proofs', 25.

18 Daniels, 'Economic Change', 969. 
utility. Eventually, we might imagine the extreme situation in which someone might own the whole world without deriving any joy or happiness from it. Most of us, of course, will not reach that saturation point. In the pursuit of enlightenment, Buddhist practice makes all of us become more efficient consumers. In this sense, Buddhist practice itself can be regarded as the most direct method for improving our efficiency in resource utilization.

It is somewhat ironic that classical economics puts so much emphasis on production efficiency but so little on consumption efficiency. Since early industrialization, millions of capital expenditure dollars were invested in equipment and technology to raise production efficiency. Continuous research and development keep searching for innovative products and new manufacturing processes to increase the variety and quantity of outputs. But more products and services generally reduce the marginal utility of consumption and intensify the consumer's addicted dependence on these goods and services. If this is not obvious to someone, just think about cocaine or other addictive drugs. Their initial consumption usually produces ecstasy and appears harmless. The consumption, however, is addictive. It will lead to more compulsory consumption. Eventually, the consumption will end up with irreparable harm to the person and collateral damage to their relatives and their society. Most consumer goods or services, of course, are not as potent and harmful as addictive drugs. But the diminishing return from consumption and the potential harm from addiction are similar. It is no coincidence that craving for consumption of goods or service is analogized to 'poison' in Buddhism.

Schumacher once observed: 'The most striking thing about modern industry is that it requires so much and accomplishes so little. ${ }^{19}$ If we are serious about efficient utilization of our scarce resources, we should invest more to improve our consumption efficiency than to improve our production efficiency. The overall payoffs and returns are much higher. Increase in production efficiency does not necessarily increase overall utility of individuals or our society. In fact, it may cause disutility if too many goods are produced beyond the saturation point. Increase in consumption efficiency, on the contrary, has only positive effects. An enlightened person will 
consume little but contribute a lot to others and our society. Because Buddhism encourages people to conserve resources and consume efficiently, any investment in Buddhistic consumer education is going to benefit our society.

\section{A Lifestyle for Efficiency}

To ensure that our society reaches overall maximal efficiency, it is imperative that everyone in our society become an 'enlightened' consumer and a productive worker. What would be required to make this a reality? An enlightened mind can not be developed without a healthy body. Per the Buddha's own experience, neither self-mortification nor self-indulgence is conducive to enlightenment. A practitioner's body needs to be nutritionally, but not excessively, fed. $\mathrm{He}$ needs to have a shelter but not a mansion. Besides food and beds, he needs clean water, air, and a safe and quiet surrounding. The desired bundle of consumption is very basic and modest, probably not much above the subsistence level found in many industrialized countries. The emphasis is on having a healthy body and a peaceful environment to prepare the practitioners for effective learning and training. A monastic practitioner's work will be teaching the Dharma. A lay practitioner needs to select a regular job that is compatible with the Buddhist definition of the 'right livelihood'. Besides work and sleep, a practitioner spends as much time on learning and training. There are two types of learning required: mind training and knowledge acquisition. Mind training enables a practitioner to become enlightened and therefore an efficient consumer and a perfect team player. Knowledge acquisition enables a practitioner to acquire knowledge and skills to become a knowledge worker. For a Buddhist, these trainings constitute part of his or her path to enlightenment.

In a traditional Buddhist education system, education is usually free to whomever desires and makes a commitment to it. The funding typically comes from contributions and donations by patrons and devotees. Of course, the operating costs are greatly reduced because the teachers and instructors are mostly volunteers or monastic practitioners who demand very little. Thus, great efficiency (in terms of external investment and regular operating funds) is demonstrated by Buddhist educational systems. Similar operating principles and 
consequences are also found in the operation of the samgha (monastic) community and other Buddhist social organizations.

\section{Modes, Scales, and Social Relations of Production}

Following Buddhist beliefs and values, the right organizational structure for production is best represented by community-based cooperatives. Production equipments and assets are jointly owned by members of the cooperatives. Output and income are distributed to members in accordance with the shares they own in the cooperatives. In an ideal situation, e.g., a monastic community, outputs and income can be distributed based on needs rather than capital contribution. Every member, regardless of rank or status, must participate in physical labor or work, as labor is considered a necessary element of Buddhist practice conducive to enlightenment. This is one of the requirements in Rules of Purity stipulated by the Chinese Ch'an Master P'ai Ch'an. Equality and full employment are goals inherent in the Buddhist production process. Members of the community do not compete, but cooperate and collaborate to achieve common goals. The agency cost problem that plagued the modern economy will be minimized. The goal of individual members is not to maximize income or to accumulate wealth, but to maximize contribution to the community, and to accumulate merits and virtues that are beneficial to the realization of enlightenment. Instead of production for profit, Buddhists labor for spiritual growth and eventual enlightenment. We can call this kind of production 'production-for-enlightenment'.

Of course, for beginners or lay persons, the production-for-enlightenment model is difficult to apply. People's attachment to ego is so strong that they need to own and possess something to feel secure and happy. As a transition, the traditional cooperative format existing in many industries in our modern economy could be adopted. Instead of maximizing profit, the goal of these cooperatives is the achievement of a required profit to meet external competition and to maintain production capacity, including the use of advanced technology. The production process should be operated at an optimal scale and involved with technologies friendly to the environment.

Regarding the scale of production, Buddhist philosophy would 
suggest that production should be carefully planned to balance cost efficiency against dysfunctional consequences resulting from excessive division of labor. Depending on the type of products and services, the scale of economy widely varies. For most products and services, as the size of production increases, the cost of production usually decreases because of the synergic effect from pooling of equipment, distribution channels, capital, and research and development. However, the attainment of economy of scale is not without social costs. Specialization may increase boredom and dissatisfaction from job routines and therefore decrease morale and creativity. Employment of more equipment and capital usually leads to substantial layoffs of workers. Mergers and acquisitions may create super entities that can monopolize global market and influence international policy and legislatures. Homogeneity of production process may also reduce economic and cultural diversity. All these negative consequences need to be carefully weighed against the gains from economy of scale. A pragmatic 'Middle Way' approach should be employed to determine the right size and the right technology that is optimal for a product. Schumacher suggested that 'intermediate technology' should be considered, as a rule, to alleviate the undesirable consequences from the use of advanced capital-intensive equipment. ${ }^{20}$

In Buddhist philosophy, all sentient beings are closely connected and interrelated in the complex network of coexistence. The earth ecology, where all sentient beings share and live, should be carefully protected in the production process. A good approach is to treat natural resources as 'capital' that requires restoration or replenishment rather than as income or expendable resources. When something is considered as 'capital', it is to be preserved permanently for continuing production and sustainable consumption. This is quite essential if we want to avoid environmental catastrophe and to ensure that our next generation has a beautiful and safe environment to enjoy.

Schumacher, Small is Beautiful, 94.

20 Schumacher, 161. 


\section{Market Mechanism and Its Limitations}

Classical economists to achieve production efficiency solely rely on the market mechanism and its effectiveness in allocating scarce resources. For the market to work as intended, a set of strong assumptions and conditions need to hold. In real-life, many of these conditions are lacking, as discussed in section II of this paper. To recap, there are substantial external benefits and costs to produce many goods and services; information is not available to everyone, significant agency costs are incurred for monitoring and enforcing contracts; there are barriers for entries, so the markets are not perfectly competitive; and, finally, many goods and services are not measurable in monetary units or exchangeable in a market.

Despite all these limitations and deficiencies, the market mechanism is still the most practical vehicle to determine price and production quantity for many goods and services. Equilibrium prices and outputs are reached when demand meets with supply. In the future, technology may advance to a point where aggregate demand and supply could be simulated in a lab to determine equilibrium price and output of a product. The development of electronic commerce, such as eBay and Amazon, makes this possibility closer to reality. Until that time, the market still has an indispensable role in our modern economy. In a Buddhist economy, the market is therefore relied upon, but its importance is considerably reduced by moderate consumption and by using other corrective measures to remedy its failure. As efficiency in consumption improves in a Buddhist economy, demand for material goods and services will decrease, releasing scarce resources for more critical needs in other areas, such as education and infrastructure. Although people may consume less goods and services, their utility and satisfaction may stay the same or even increase. Subsidies or taxes will be used to internalize social benefits or costs so that production of goods or services will reflect true benefits and costs to our society. Government ownership will be encouraged to produce public or naturally monopolized goods or services. Community ownership of assets and equipment, such as cooperatives, will be promoted to reduce agency costs and financial frauds. A consumption-based tax system will be introduced to discourage the consumption of socially or environmentally undesirable goods 
or services. Death and progressive income taxes will be imposed to eliminate accumulation of personal wealth.

\section{Social Priorities and Institutions}

Wisdom and compassion are the two pillars of enlightenment. The priorities of a Buddhist economy therefore reside in education and social well-being. The education required here is a holistic endeavor integrating two parts: the learning of Buddhist values and the learning of worldly knowledge. In Buddhist cannons, these two aspects of learning are referred to as the learning of the 'ultimate truth' and the learning of the 'worldly truth'. The two truths are two aspects of the same ideal and therefore should be integrated and fused. Understanding of the ultimate truth will lead to enlightenment which will transform an ordinary consumer into a supreme consumer with unsurpassed efficiency in consumption as discussed in the previous section. Understanding of the worldly truth essentially entails the study of sciences and technology which are instrumental in achieving production efficiency.

To ensure efficient utilization of our scarce resources, both consumption and production efficiency are essential. Our current education system is very successful in the instruction of science and technology, but very weak in the instruction of ultimate truth or metaphysical wisdom. There is also very little effort to integrate the two. Most mainstream educational institutes have conscientiously separated the two as if they would contaminate each other. Even in the general education curriculum of universities and colleges, knowledge from these two perspectives is instructed separately in different courses. Each of the perspectives has been developed without interaction with the other. There is no common philosophical foundation or a comprehensive conceptual framework on which dialogues or discussions can be based. Divinity and humanity never intersect. Instead, they conflict and compete. In Buddhist philosophy and its education system, the two perspectives are seamlessly interwoven into a holistic and supreme understanding of reality.

In an ideal Buddhist society, social well-being and individual well-being are aligned in perfect harmony. When a person's ego is conquered, social well-being becomes identical with individual 
well-being. For example, for a bodhisattva, the sentient being's suffering is his or her suffering; and the sentient being's happiness becomes his or her happiness. This implies that social well-being always carries more weight than individual well-being. Thus, in a Buddhist economy, social goals such as education of general populace, equality of opportunity, harmony of community, economic stability, and protection of environment are weighed much more heavily than protection of individual freedom and rights, maximization of individual utility and consumption, or cost minimization in production. Without doubt, in a Buddhist economy, collectivism and socialism play a much more important role than individualism or market mechanism. Community or common ownership will be more prevalent than individual ownership. Shared governance and democracy will be applied not only to the production and distribution of public goods, but also to the production of private goods as practically feasible. In fact, for an enlightened person, no goods or property is private. First, there is no 'self' to 'own' anything. Second, minimal consumption from such a person would not require the person to own many assets or properties. Third, attachment to ownership is a hindrance to enlightenment. Lastly, all beings are closely related; legal separation and artificial boundary mask the inter-connective nature of reality.

In a Buddhist economy, cooperative types of organizations will replace private profit-seeking corporations as much as possible. Labor unions and big corporations will have less reason to exist and will play a less important role. If they exist, they will be closely monitored and regulated in terms of size and operation. Decentralization would be the preferred principle form of government and business organizations. Centralized government functions are used only when definite benefits from economy of scale are present or for pure public goods or services. The role of ethics and professional codes will become more important. Contract and legal arrangements will be simplified and only used to ensure efficient market mechanism. Equitable and definitive tax systems will be preferred to big government for redistribution of income and wealth. Terms and treaties of international trade will place more emphasis on mutual benefits and equal opportunity. National differences and cultural diversity will be respected. Market and production efficiency will not be the 
only goal. Globalization and world-wide industrialization will be slowed to ensure balance in environmental protection and economic growth. The long-term goal of sustained growth will replace the short-term goal of profit maximization for individual enterprises, as well as for national economies.

\section{Implementing Buddhist Economics}

Unlike technological changes, social changes are slow and painstaking. Conventional economic thoughts have permeated and dominated every aspect of our life for more than several hundred years. They are almost our second nature now. Many of us consider the market/ capitalist economic model as a self-evident truth that requires no proof. It is elevated to the status of a quasi-religion. Every one of us knows the difficulty involved to convert someone from one religion to another religion. To convince the mainstream economists that Buddhist economics is a viable alternative would encounter as much resistance as converting someone to a new religion. It would require a complete revolution or overhaul of our current education system which does a good job in dissecting knowledge into specializations without restoring them back to a whole. Schumacher stated:

What is at fault is not specialization, but the lack of depth with which the subjects are usually presented, and the absence of metaphysical awareness. The sciences are being taught without any awareness of the presuppositions of science, of meaning and significance of scientific laws, and of the place occupied by the natural sciences within the whole cosmos of human thought. The result is that the presuppositions of science are normally mistaken for its findings. Economics is being taught without any awareness of the view of human nature that underlies present-day economic theory. In fact, many economists are themselves unaware of the fact that such a view is implicit in their teaching and that nearly all their theories would have to change if that view changed...

Education cannot help us if it accords no place to metaphysics. Whether the subjects taught are subjects of sciences or of the human- 
ities, if the teaching does not lead to a clarification of metaphysics of our fundamental convictions, it cannot educate a man and, consequently, cannot be of real value to society. ${ }^{21}$

These statements by Schumacher are quite insightful and awakening. In Buddhist economics, the so-called 'metaphysics' is no metaphysics at all. It is a natural extension of modern 'sciences' or 'humanities', or a necessary restoration of them back to their proper statuses in a coherent and complete knowledge system. As elaborated in the previous sections, conventional economics chooses to limit its enquiry solely to the achievement of production efficiency, ignoring entirely the issue of consumption efficiency. It concentrates only on half of the efficiency problem that is easy to quantify and analyze. It excludes the other half of the efficiency problem that requires a deep understanding and insight about human nature. It may be understandable why classical economists such as Adam Smith opted for such an easy way out several centuries ago. At that time, thoughts like humanistic Buddhist philosophy were not familiar to Western philosophers at all. Today is the right time for East to meet with West and for human knowledge to be restored to truly benefit humans and their environment.

\section{IV.1 The Need for a Revolution in Education}

The starting point is our education system. Our current education system that produces modern scholarship is seriously flawed. Scholars and researchers in science and humanities are educated in a fragmented way. Incomplete knowledge is the whole truth and the only truth. The most fundamental wisdom, the 'mother' of all knowledge - the metaphysics or the presuppositions of sciences-is completely ignored. Each individual discipline deals with certain aspects of human problems without a common underlying 'center' to unite them together. Thus, even though we are in a knowledge-explosion age (the word 'explosion' is quite descriptive of the fragmented nature of

\footnotetext{
21 Schumacher, Small is Beautiful, 86.
} 
modern scholarship), with all the knowledge we have, no one knows where all this knowledge leads us. We are completely torn apart and lost in disintegration. If everyone realizes the inherent limitation and weakness of modern science and technology and adopts a cautious approach of trial and error, things may not be this bad. But our blind faith in modern science and technology has made us believe that humanity will prevail no matter what happens. The conviction of unabridged individual freedom and rights has led us to a new religion characterized by materialism and consumerism. Some consequences of this new religion and its impact on human life were described in the first section of this paper.

To make the transition from our current economy to a Buddhist economy, an overhaul of our education system is absolutely needed. It requires all of us, citizens and the government, academicians and non-academicians, to take an entirely new approach to scholarship and human knowledge acquisition. But the formal education system (the $\mathrm{K}-12$, higher education, and post-graduate education) and the scientific community must bear the most responsibility, because they are the evangelists and advocates of this new religion of pseudo-economics. Through them, consumerism and egocentrism become the 'correct view', 'correct thought', 'correct speech', 'correct behavior', and 'correct livelihood', while, in fact, they are perpetrating negative karmas that ensure their infinite stay in the cycle of birth and death. To break the tight reign of samsāra (cycle of suffering), our education system needs to borrow heavily from Buddhist education and training. Skills on meditation and concentration, the insight of 'emptiness' and 'Middle Way', and the non-duality of the ultimate truth and worldly truth should be important components of our new scholarship and education.

\section{IV.2 Ethical Consumption}

For a Buddhist, the goal in this life is spiritual awakening or enlightenment, because enlightenment signifies the cessation of all suffering and the achievement of supreme bliss. To achieve this goal, a practitioner should use wisely all the resources available to him, including his body, his mind, and his worldly belongings. For a Buddhist, con- 
sumption is not an end as it often is in the West, where consumption is regarded as a prime engine of economic growth. In contrast, Buddhists see consumption as a tool: it provides the material platform needed to support the spiritual work of achieving enlightenment. Beyond that, consumption of goods or services poses a threat to the practitioners if they become too attached to them. A Buddhist needs to be able to overcome the desire for excessive consumption and concentrate his energy and endeavor on mind training and spiritual growth. This discipline on consumption is difficult to achieve in a culture of mass consumption, where advertisers conflate needs and desires and promote acquisitiveness. But in developing countries, there is an encouraging example. Since 1958, a grassroots development effort in Sri Lanka, known as Sarvodaya Shramadana, has promoted village-based development programs that explicitly integrate material and spiritual development. Sarvodaya Shramadana can be roughly translated as 'awakening of all through sharing'. Villagers involved with the movement undertake a broad range of development projects, from latrine building to establishment of preschools and cultural centers, within a framework of Buddhist principles. The movement has grown to encompass more than half of the country's 24,000 villages and is now the largest NGO (Non-Government Organization) in Sri Lanka. ${ }^{22}$

One of the distinguishing features of the Sarvodayan vision of development is that it explicitly and deliberately includes not just the material requisites for a dignified life, but also the educational, social cultural, and spiritual requirements. This holistic perspective is reflected in the following list of ten major human needs that guide the development:

1. A clean and beautiful environment,

2. A clean and adequate supply of water,

3. Basic clothing,

4. A balanced diet,

5. A simple house in which to live,

22 Gardner, Invoking the Spirit, 39. 
6. Basic health care,

7. Simple communication facilities,

8. Basic energy requirements,

9. A well-rounded education, and

10. Cultural and spiritual sustenance.

This list of ten basic needs reflects the consumption ethics of the movement. ${ }^{23}$ By placing spiritual needs on a par with material ones, it reminds people of the importance of spiritual needs and how they can be subverted by attachment to material goods. The list also serves as a guide for consumption. Anything beyond the ten needs would be considered as expressions of 'greed, sloth, or ignorance', and therefore counter-productive to a Buddhist practice. By restraining excessive or unproductive human desire, ethical consumption reduces the financial capital and technology requirement for a developing economy, eliminates the need to exploit human labor and natural environment, and facilitates the development of a harmonious and sharing society.

The Sarvodaya movement may not be readily applicable to other parts of the world or to most of the developed countries, because of the sharp difference in culture and value system. However, any educational efforts to curtail people's compulsive need for consumption and other governmental measures to discourage excessive consumption (e.g., taxes on excessive or luxury consumption) would move our modern world toward a more balanced and sustainable economic development.

\section{IV.3 Responsible Use of Labor and Natural Resources}

The same spirit applied to consumption should also be applied to production. If consumption needs to be constrained and redirected to achieve optimal efficiency, production needs to be restrained and planned to achieve long-term sustainability and stability. Important factors in the production process are land and its natural resources.

\footnotetext{
23 Gardner, Invoking the Spirit, 40.
} 
In modern economics, land and natural resources are treated as expendable means to produce goods and services for human consumption. Beneath this utilitarian view of the land is the metaphysical view that humans are the center of the universe and that everything exists to support human existence and comfort. But is man the master of nature or its child? As Schumacher wrote:

...One of the most important tasks for any society is to distinguish between ends and means to ends, and to have some sort of cohesive view and agreement about this. Is the land merely a means of production or is it something more, something that is an end itself? And when I say 'land', I include the creatures upon it. ${ }^{24}$

If we examine the classical economics theory carefully, it fails miserably in this important task of defining and distinguishing ends and means. In the classical consumption theory, economists conveniently assume that utility comes mainly from consumption of goods and service. The assumption implies that consumption is the ends, not means, to other higher-level achievement-an assumption that clearly ignores the complexity of human nature and contradicts the science of psychology. In the classical production theory, economists consider labor and land as expendable inputs. But the well-being of labor and land are ends pursued by men since the beginning of the history of mankind. If economic theory likes to become a truly 'rational' science, it needs to shed its past by seriously reconsidering its treatment of consumption as final goals and the use of land and labor as pure means. It needs to adopt a new production theory in which labor and land are both means and ends simultaneously, and that they are something to invest and enrich just like capital. When they are depleted in the production process, they need to be replenished, maintained, and even improved just like other capital equipment. This 'capital' perspective of labor and land is fully in line with the Buddhist view that a bodhisattva's goal in this life is to protect, benefit, and deliver all sentient beings. In Buddhist economics, therefore,

\footnotetext{
24 Schumacher, Small is Beautiful, 98.
} 
protection and preservation of the natural environment and enrichment and empowerment of employees are considered as important as the accumulation of capital. In fact, the accumulation of capital is a means to achieve these goals.

The Buddhist view on the environment and its role in the development of modern economy is shared by many religious leaders, as well as by environmentalists. ${ }^{25}$ For example, in Europe an organization called Religion, Science and Environment (RSE) was established by Ecumenical Patriarch Bartholomew to address the environmental issues in the Aegean Sea, the Black Sea, down the Danube River, and in the Adriatic Sea. In Thailand, 'environmental monks' are gaining fame for their advocacy of conservation and social justice within the Buddhist framework. The most successful example comes from the Thai village of Giew Muang, where in 1991 Prhaku Pitak helped to restore a forest used by ten surrounding villages that had been degraded and denuded by decades of exploitation. Another case was the cleanup efforts of the Ganges River, led by Dr. V. B. Mishra, a hydrologist and professor of civil engineering who has been working for more than two decades to rid the river of contaminants. In accounting, there is an effort to require firms to disclose the impacts of their operations on the environment so that the public and investors can be adequately informed about these impacts. ${ }^{26}$

The Buddhist view on the development of human potential and the dual role of labor in the development of modern economy is consistent with the social justice call reflected in religious proclamations, the modern labor movement, and progressive managerial practices. For example, the encyclicals of Pope John Paul II (especially Laborem Exercens, Sollicitudo Rei Socialis, and Centesimus Annus) and the 1986 United States' Bishops' pastoral letter on the economy (Economic Justice for All) clearly stated the value of human dignity, safe working conditions, and equitable distribution of income. ${ }^{27}$ The

\footnotetext{
25 Gardner, Invoking the Spirit, 28.

26 See the website of the Sustainability Accounting Standard Board (SASB) https://www.sasb.org/.

27 Alexandrin and Zech, 'Ancient Futures', 1344.
} 
modern labor movement and the formation of labor unions in the twentieth century represent initial actions taken by the workers in their struggle to improve their working conditions and their shares of economic income. Their struggle and battle, however, are still based on the classical economic framework of treating labor as means rather than ends. The acceptance of the market mechanism as the basic economic model in their collective bargaining process is self-devaluating and contributes to the decline of the union in the last two decades of the twentieth century. ${ }^{28}$ Because of increasing economic uncertainty and rapid technological changes, there is an increasing emphasis on the development and empowerment of employees in corporate America. More and more companies have realized the important impact of quality employees on their bottom line. Spending on employee training and development is considered essential in maintaining competitiveness in the global market. Many Fortune 500 companies have made employee training and development one of their strategic goals. The achievement of this goal is formally evaluated annually in a performance evaluation scheme called 'balance scorecard'. ${ }^{29}$ Although the motivation behind this trend is still profit, it corroborates the statement that labor is not just an input factor but also a goal by itself.

As was emphasized before, any social change is necessarily evolutional rather than revolutionary. The transition from conventional economics to Buddhist economics can not take place overnight. In fact, the change, if any, is indeed slow and painstaking. Although pockets of success are reported here and there, the pervasive changes probably won't be seen for decades.

\section{IV.4 Equitable and Productive Ownership of Assets}

Equality is an important social and economic goal in most cultures and societies. Human experience values and prioritizes equality because it promotes social peace and stability. From an economic per-

Carson, Economic Issues, 135.

29 Norton and Kaplan, The Balanced Scorecard.
} 
spective, equality also plays a very important role. For a free market to work, the market requires every participant to have equal access to relevant information, equal right to enter and transact, and equal influence on the demand and supply of the market. If information, entry and transaction, price and quantities of goods are monopolized by a few persons, the market will fail to allocate our scarce resources in the most efficient manner. Unfortunately, in real-life each of us came with an unequal endowment in wealth, as well as in talents. This inequality in endowments is further amplified by the existing laissez-faire capitalistic system. The rich are becoming richer and the poor poorer. Since market cannot be relied upon to achieve an egalitarian society, a natural response is to eliminate it and replace it with a government planning system which nationalizes all productive assets. However, a national planning system is not without its own problem. First, the governed and the governing are unequal in their access of information and in their influence on the policy-making process. Consequently, economic decisions made under such a system may not reflect the best interest of the governed majority. In fact, experience has shown that a lot of corruption and waste is found in such a system. Second, national ownership is often plagued with the free-rider problem. There is little incentive for hard work and innovation. The collapse of the communist block seems to corroborate these observations.

A third alternative, community ownership, which is frequently considered archaic and has made a minimal contribution to modern economy by conventional economists, holds the promise of being a skillful compromise between the two extremes of laissez-faire and national planning. A 'community' is usually a group of individuals whose interactions are long-term, frequent, and personal. In this sense, community includes family; residential neighborhoods; workplaces, as well as formal governance structure, such as cooperatives; mutual credit associations; and worker- owned and managed enterprises. ${ }^{30}$

Compared to the other two alternatives, community ownership

30 Ostrom, Governing the Commons. 
has several advantages. First, a community is organized on the principles of democracy and equality. Second, community members are bound by strongly shared norms and ethics that encourage members to behave in the long-term interest of the community, preventing exploitation of the environment at the expense of intergenerational equity. Third, the heavy interaction among community members allows members to monitor each other's behavior without the incurrence of expensive agency costs and thus alleviates the free-rider problem. Fourth, a community fosters cooperation and collaboration rather than competition and confrontation, avoiding unnecessary internal conflicts and frictions and thus increases overall organizational productivity and efficiency. All these characteristics and properties of a community governance structure are consistent with Buddhist principles of selflessness and compassion. In fact, the traditional samgha (Buddhist monastery) communities are organized based on the same principles and represent a perfect example of this type of governance. $^{31}$

Schumacher gave a successful example of community-owned enterprises and suggested a possible new pattern of ownership that mimics this type of ownership structure. ${ }^{32}$ The Scott Bader Commonwealth established in 1951 is a British enterprise in which its original owner (Scott Bader) relinquished his entire ownership of the enterprise to his employees with the following stipulations:

1. The firm shall remain an undertaking of limited size $(350$ persons or thereabouts) so that every person in it can embrace it in his mind and imagination;

2. Remuneration for work within the organization shall not vary, as between the lowest paid and the highest paid, beyond a range of $1: 7$ before tax;

3. As the members of the Commonwealth are partners and not employees, they can not be dismissed by their co-partners for any reason other than gross personal misconduct;

\footnotetext{
31 Hsing Yun, A Buddhist Approach.

32 Schumacher, Small is Beautiful, 256.
} 
4. The Board of Directors shall be fully accountable to the Commonwealth. The Commonwealth has the right and duty to confirm and withdraw the appointment of directors and to agree on their level of remuneration;

5. A minimum of 60 percent of net profits should be retained for taxation and self-finance. The Commonwealth shall devote one-half of the remaining 40 percent to the payment of employee bonuses and the other half to charity organizations; and

6. None of the products of the firm shall be sold to customers who are known to use them for war-related purpose.

The collectivized ownership turned out to be a big success in the highly competitive setting within which it operated. Between 1951 and 1971, the firm increased its revenues from 625,000 pounds to 5 million pounds; its net profits grew from 72,000 pounds to nearly 300,000 pounds a year. Encouraged by the success of the Scott Bader Commonwealth, Schumacher suggested a manner by which, private-held corporation can be transferred into a community-owned business enterprise. The scheme would require a private company to double its current common shares by issuing an equal number of new shares and transferring the ownership of these new shares to a 'Social Council' elected and controlled by the public. The 'Social Council', as fifty percent owner of the enterprises, will be entitled to fifty percent of the firm's before-tax profits and its residual interests. If companies adopted this form of collective ownership, these companies would be exempt from income taxes.

Although few firms exist with the democratic structure described above, a good number of close approximations can be found in the modern economy. Studies have shown that these firms have higher productivity than their capitalist counterparts. ${ }^{33}$ Other relevant evi-

33 Levine and Tyson, 'Participation Productivity', 183; Weitzman and Kruse, 'Profit Sharing', 95.

34 Rosser, et. al., 'New Traditional Economy', 763; Wilson, Economics, Etbics and Religion; and Prayukvong, 'A Buddhist Approach to Economics', 1171. 
dence on the desirability of broader application of community ownership in economic development can be found in studies conducted by Rosser et. al., Wilson, and Prayukvong. ${ }^{34}$ In several Asian regions, such as Japan, Taiwan, Singapore, and Hong Kong, Confucianism is one of the contributing factors toward the economic success registered in these countries. The core values of Confucianism are loyalty, conformity, compassion, mutual respect, and justice. These values are closely related to community values. The emphasis on family rather than individuals as the basic organizational form in social and economic activities is a long tradition in these countries. In Japan, family relations and values are further extended and applied to the organization of business enterprises or groups of these enterprises. Despite the legal shell of a corporate structure, a business enterprise functions very much like a family internally, making the enterprise a de facto 'community'. Thus, practices that generally existed in a family relationship are found in Japanese corporations: group decision process, life-time employment, sharing of income and profit in the form of handsome bonuses to employees, parity in compensation, mutual respect, and social insurance. Because of these practices, the Japanese economy could grow from a war-ruined economy to an economic powerhouse in a very short period.

Once considered as archaic and inept in today's economic environment, community ownership and its governance structure holds the future of a new economic order in which careful balances are maintained between short-term production efficiency and long-term sustainable growth, between materialistic gains and spiritual growth, and between individual well-being and social welfare. This form of governance is underutilized in our current problems-laden economic system. Any efforts by governments to induce wider usage of this form of ownership could potentially move our modern economy into a new frontier.

\section{IV.5 A Pragmatic Middle Way Approach}

When it comes to an economic philosophy or approach, most people easily fall into an ideology or philosophical camp. There is a good reason for this: the economic problem to be solved and the variables 
involved are extremely complicated. Without assuming certain presuppositions, the problem is almost intractable. Thus, economists and policy makers must fall back on certain assumptions to support their decisions or policies. In so doing, most of them adopt a reductionist's approach of using an over-simplified model to address an inherently complex problem. They rely too much on assumptions and presuppositions, and too little on facts and causal links. They are long in passion and enthusiasm and short in rationality and empiricism. They are either conservative or liberal; capitalists or communists; Neoclassical or Keynesian; demand-side or supply-side. Unfortunately, reality is none of the above and can hardly be represented by views from any angle or perspective. In Buddhist philosophy, there are constant warnings to practitioners regarding the danger of attaching to extreme views, means, and practices. Extreme or partial views are false views that should be avoided at any cost. They impede enlightenment and contribute to human suffering and conflicts. A practitioner should take a Middle Way approach free from extremes and skillfully select a best solution depending on conditions and circumstances.

Following the Middle Way approach, a Buddhist economist would not prescribe a universal approach to economic problems. Depending on circumstances and contexts, a variety of measures would be alternatively applied to reach goals and objectives. The Middle Way path applies to both microeconomics and macroeconomics. For example, on the issue of optimal consumption, one cannot pursue exclusively for self-interest or public interest. Pathompituknukoon and Suriya constructed individual utility functions to examine if an individual will be happier when he or she spends time and financial assets for self or public interests. ${ }^{35}$ Through dynamic optimization, they investigated trade-off between time and the assets donated for public interests as the mean to happiness. They concluded that an individual cannot live in an extreme way by spending all the time for self-interest while spend all financial assets for other people and vice versa. The study confirms that the middle path in Buddhist Eco-

\footnotetext{
35 Pathompituknukoon and Suriya, 'Mathematical Proofs', 25.
} 
nomics is consistent with the optimality in economics, and it is the pathway to the maximum of happiness.

On the issue of organization and ownership, Buddhist understands that none of the three alternatives (market, state, and community) has absolute advantage over the other two under all circumstances. Each of them has its strengths and weaknesses to produce certain goods and services and for the achievement of different social and economic goals. When perfect competition conditions are present or approximated, the market is very efficient in allocating our scarce resources. When those conditions are not present, the market will fail and the state must step in. But state bureaucracy usually induces corruption, waste, and inefficiency; therefore, decentralized communities are preferred if the scale of operation is manageable by the communities. Community ownership, however, is limited in its scope of operation and weak in providing incentives for innovation. Bowles and Gintis clearly stated this point. ${ }^{36}$ They argued that the three alternatives are complementary to each other and therefore should be mixed to achieve Pareto optimality.

Similarly, the pragmatic Middle Way approach can be applied regarding the use of technology and the global trade agreement. One of the frequent mistakes made by the developing countries is that advanced and capital-intensive technology is always preferred for economic growth. Many developing countries borrowed heavily to import expensive state-of-the-art machinery and equipment only to find out that there were not enough trained workers to operate and maintain the equipment. They paid a handsome price to learn that technology alone does not make an economy grow; that industrial equipment needed to be supported by industrialized education and a culture system; and that intermediate technology may be more productive under certain cultural and social structures. In developed countries, advanced technology is sometimes overused. In the healthcare industry, for instance, research and development in new drugs and new treatment methods have driven the healthcare costs so high that many people in these countries can no longer afford them. More

36 Bowles and Gintis, Recasting Egalitarianism, 9. 
people would be benefited if intermediate technology were utilized in the healthcare system.

In the international trade arena, a uniform global trade pact is pursued aggressively by the World Trade Organization (WTO). It is believed that free trade under a gigantic global market framework universally benefits every participating country. The global market idea is imposed on many developing countries without any consideration of their stages of economic development, their social and culture structures, and their unique goals and priorities. As discussed in the previous section, the free market mechanism only works when the market participants have equal access to information and equal influences on the supply and demand of the goods or service. This condition certainly does not exist among different countries in different stages of economic development with different levels of technology and capital. Even in developed countries, the market mechanism is frequently modified by governmental intervention to protect certain domestic industries. For example, agricultural industries in the United States and Japan are heavily protected and subsidized. How can the market mechanism be solely relied upon to advance global trade? A Buddhist approach to the global trade issue will necessarily seek a balance between local autonomy and market tyranny, between cultural diversity and materialistic consumerism, and between environmental protection and economic growth. It would allow each region or country to preserve certain social and economic features while they move toward gradual opening of their domestic markets.

\section{Conclusion}

The most striking thing about our modern society is that it consumes so much yet accomplishes so little. In developed countries, we have so many goods and services for consumption that we started to develop a throw-away economy. In such an economy, our marginal utility derived from materialistic consumption is so low that incremental consumption yields little enhancement in our satisfaction. Furthermore, our disutility from garbage and pollutants is increasing rapidly because of the bulk of wastes and refuse created by our con- 
sumption and production. In other parts of the world, there is severe shortage and scarcity. People are starving and struggling in many developing countries. If you were God, you would not be very proud or happy about this uneven distribution of goods and wealth on earth. You would do something to improve the overall welfare of mankind. You would encourage more efficient consumption and ensure fairer income redistribution.

Economic problems aside, our pursuit for economic development and materialistic consumption has caused a plethora of complications and side effects. The rationalization of self-interest as the power generator of our modern economic machines has created a competitive and hostile society in which shared moral standards such as integrity, love, and altruism are almost entirely vanished. If they still exist, they usually become objects of ridicule. The severe industrial pollution and the relentless deforestation have made our mother earth lose all its vital signs. The 'living' planet has lost so many living species and creatures that the modifier 'living' may no longer apply. Crime, conflicts, and wars are looming and lurking in so many places where people live in great despair and agony. Schumacher wrote: 'are there not indeed enough 'signs' of the time to indicate that a new start is needed?' ${ }^{37}$ Fifty years later, the 'signs of the times' have not dwindled but multiplied.

The biggest problem in our modern society lies in our blind faith in the conventional economic theory and its presuppositions. Modern economists have sold us something disproportionately exaggerated. We are told that consumers have the highest sovereignty in our modern world, that the market is supreme and 'the invisible hand' is our 'God' in determining what is 'good' and 'bad'. If we keep on consuming, we will be all blessed with long-term economic prosperity and stability. Someday, we will reach 'heaven' as income and wealth trickle down from the rich to the poor. We are convinced that competition and desires will lead to innovation in technology which will solve all our problems eventually, if not now. Since we have already had our 'God', we do not need any other religions. In fact,

\footnotetext{
37 Schumacher, Small is Beautiful, 70.
} 
we are so confident in our economic 'God' that we do not have the slightest hesitation to subject all other Gods to market and economic analysis in a new research area dubbed 'Economics of Religions'. Our faith in this economic God grew exponentially in several centuries as mainstream media and formal education systems were all called upon to serve this God. Since all of us subscribe to this God, this religion of economics appears to be so self-evident and universally true that we give this religion a name called 'The Science of Economics'. We are so frenzied and passionate about this religion that we ignore all the 'signs of the times' that try to awaken us. The 'Science of Economics' is like a big religious cult. Our dreams, nonetheless, must be awakened or shattered sooner or later because that is what happened to all fanatical cults. It is ironic that the motivating force behind the whole Renaissance movement, including the origin of modern economics, is to liberate mankind from the cuffs and shackles of dogmatic religious thoughts. Unfortunately, as men were just freed from the incarceration of one extreme, they immediately embraced another extreme-something seemingly different but as dogmatic and religious as the other. This is not particularly surprising. As indicated often in Buddhist literature, sentient beings have a strong propensity to attach to extreme or wrong views, leading themselves to go through cycles of arising and extinguishing. The only way out is self-awakening and the determination to follow a Middle Way approach.

Buddhist economics, as outlined in this paper, represents an innovative and evolutionary approach to human economic problems. Unlike conventional economics which takes a disintegrated perspective and a piecemeal approach to human economic problems, Buddhist economics takes an integrative perspective and a holistic approach to those problems. It appropriately considers economic inquiry in the totality of human knowledge toward the ultimate solution of human happiness and well-being.

In classical economics, humans are considered the center of the whole universe; everything else serves humans and is therefore expendable for the enjoyment of humans. In Buddhist economics, humans are considered only a member of the earth ecology; other beings and non-beings shared the earth and the universe with us. Human well-being depends on the well-being of other members of 
our ecological community. If we do not deceive ourselves, it is obvious which perspective is more descriptive of the reality.

In classical economics, labor is just a production factor like machines or equipment. Work represents disutility to which all men are averse and will try to avoid if they have enough to spend. In Buddhist economics, workers are the 'ends' as well as the 'means'. They are not only producers but also the 'goods' they produce. Work itself can produce great utility if the workers are respected as decent human beings (or even better-'the Buddha-to-be') and the working environment is structured to facilitate the learning of wisdom. If we do not devalue ourselves, it is obvious which perspective adopts a more positive attitude toward humanity.

In classical economics, education is mostly considered as consumption. In Buddhist economics, education is the single most important investment that a society can make. If we do not humiliate ourselves, it is obvious which perspective is more productive.

In classical economics, everyone only looks after his or her own interests. People compete and fight for more resources. The world is mostly a zero-sum game. In Buddhist economics, everyone looks after each other. People cooperate and collaborate. The world is a win-win game. If we do not demoralize ourselves, it is obvious which perspective is more spirit-lifting.

In classical economics, market dictates everything; value is determined solely by quantity of demand and supply without reference to any intrinsic worth. Popularity becomes the only criterion for success. In Buddhist economics, rationality is in charge. Value is determined by its long-term contribution to human happiness and well-being. Enlightenment is the only criterion for success. If we do not delude ourselves, it is obvious which approach is more effective in achieving the final human goal.

In classical economics, individual rights are unlimited and laissez-faire is the paramount mode. In Buddhist economics, individuals are respected, yet their freedoms are subjugated to the need for social harmony and justice. Sharing and altruism is the fundamental mode. If we do not indulge ourselves, it is obvious which approach leads to a more harmonious society.

In classical economics, divergent and conflicting ideologies are 
competing to serve as the main platform for all economic policies and actions. They are usually extreme views that represent partial reality or rigid dogma. In Buddhist economics, skillful means are integrated into coordinated and balanced programs to ensure highest social well-being. The approach can not be characterized as either left or right; either conservative or liberal. It is open, experimental, pragmatic, and eclectic. It is the Middle Way. If we do not deceive ourselves, it is obvious which approach is more feasible and practical to solve our economic problems.

\section{Bibliography}

Alexandrin, G. 'Elements of Buddhist Economics'. International Journal of Social Economics 20, no. 2 (1993): 3-11.

Alexandrin, G., and C. Zech. 'Ancient Futures: Papal and Buddhist Economics'. International Journal of Social Economics 26, no. 10/11 (1990): 1344-53.

Ash, C. 'Do Our Economic Choices Make Us Happy'. In Ethical Principles and Economic Transformation-A Buddhist Approach, edited by L. Zsolnai, 11-131. New York: Springer, 2011.

Bowles, S., and H. Gintis. Recasting Egalitarianism: New Rules for Communities, States and Market. London: Verso, 1999.

Brown, C. 'Buddhist Economics: An Enlightened Approach to the Dismal Science'. Challenge 58, no. 1 (2015): 23-28.

-_- Buddhist Economics: An Enlightened Approach to the Dismal Science. New York: Bloomsbury Press, 2017.

Carson, R. B. Economic Issues Today: Alternative Approaches. New York: St. Martin's Press, 1991.

Choudhury, M. A. 'Islamic Economics as a Social Science'. International Journal of Social Economics 17, no. 6 (1990): 35-59.

Daniels, P. 'Buddhist Economics and the Environment: Material Flow Analyses and the Moderation of Society's Metabolism'.

International Journal of Social Economics 30, no. 2 (2003): 8-33.

_-_. 'Buddhism and the Transformation to Sustainable

Economies'. Society and Economy 29, no. 2 (2007): 155-80.

- - . 'Economic Change, the Environment, and Buddhism in 
Asia'. International Journal of Social Economics 25, no. 6/7/8 (1998): 969-1004.

- _ - 'Economic Systems and the Buddhist World View: The 21st Century Nexus'. Journal of Socio-Economics 34, no. 2 (2005): 245-68.

Gardner, G. Inspiring Progress: Religions' Contributions to Sustainable Development. New York: W. W. Norton and Company, 2006.

- - Invoking the Spirit: Religion and Spirituality in the Quest for a Sustainable World. Washington D.C: Worldwatch Institute, 2002.

Gowdy, J. 'Business Ethics and the Death of Homo Economicus'. In Business within Limits: Deep Ecology and Buddhist Economics, edited by L. Zsolnai and K. Ims, 83-102. Oxford: Peter Lang Academic Publisher, 2006.

Golden, T. A. 'The Relevance of Buddhist Economics: Capitalism, Morality, and the Global Financial Crisis'. Senior Thesis, Lingnan University, 2009.

Groenewegen, P., ed. Economics and Ethics?. London: Routledge. 1996.

Hauseman, D. M., and M. McPherson. Economic Analysis, Moral Philosophy, and Public Policy. Cambridge: Cambridge University Press, 1996.

Heilbroner, R. The Limits of American Capitalism. New York: Harper and Row, 1966.

Henley, Andrew. 'Economic Orthodoxy and the Free Market System: A Christian Critique'. International Journal of Social Economics 14, no. 10 (1987): 56-66.

Hsing Yun 星雲. A Buddhist Approach to Management. Translated by Otto Chang. Hacienda Heights: Buddha's Light Publishing, 2001.

Inoue, Shinichi 井上信一. Putting Buddhism to Work: A New Approach to Management and Business. New York: Kodansha International, 1997.

- - - 'A New Economics to Save the Earth: A Buddhist Perspective'. In Mindfulness in the Marketplace: Compassionate Responses to Consumerism, edited by A. Badiner, 49-58. 
Berkeley: Parallax Press, 2002.

Kent, C. A. 'A Christian Approach to Social Economics'. International Journal of Social Economics 13, no. 3 (1986): 80-92. Keynes, J. 'The end of Laissez Faire'. In Essays in Persuasion, by J. Keynes, 312-22. New York: Norton, 1963.

Khan, M. A. 'The Future of Islamic Economics'. Future 23, no. 3 (1991): 248-61.

Levine, D. L., and L. Tyson. 'Participation Productivity and the Firm's Environment'. In Paying for Productivity: A Look at the Evidence, edited by A. Blinder, 183-244. Washington D.C: Brookings Institution, 1990.

Lyubomirsky, S. The How of Happiness: A Scientific Approach to Getting the Life You Want. New York: Penguin Books, 2008. Nelson, R., and M. L. Stackhouse. Economics as Religion: From Samuelson to Chicago and Beyond. University Park: Pennsylvania State University Press, 2014.

Norberg-Hodge, H. 'Buddhism in the Global Economy'. In Mindfulness in the Marketplace: Compassionate Responses to Consumerism, edited by A. Badiner, 15-27. Berkeley: Parallax Press, 2002.

Nortin, D., and R. Kaplan. The Balanced Scorecard: Translating Strategies into Action. Cambridge: Harvard Business School Publishing, 1996.

Oslington, P. 'A Theological Economics'. International Journal of Social Economics 27, no. 1 (2000): 32-44.

Ostrom, E. Governing the Commons: The Evolution of Institutions for Collective Actions. Cambridge: Cambridge University Press, 1990. Pathompituknukoon, P., and K. Suriya. 'Mathematical Proofs of the Middle Path in Buddhist Economics as a Pathway to the Maximum of Happiness'. The Empirical Econometrics and

Quantitative Economics Letters 3, no. 1 (2014): 25-32.

Payutto, P. Buddhist Economics: A Middle Way for the Market Place.

Bangkok: Buddhadhamma Foundation, 1994.

- - - Buddhism and the Business World-The Buddhist Way to

Deal with Business. Bangkok: Mahachulalongkornrajavidyalaya

University, 2009.

Prayukvong, W. 'A Buddhist Economic Approach to the Development 
of Community Enterprises: A Case Study from Southern Thailand'. Cambridge Journal of Economics 29 no. 6 (2005): $1171-85$.

Pryor, F. L. 'A Buddhist Economic System-In Principle'. American Journal of Economics and Sociology 49, no. 3 (1990): 339-49.

- - - 'A Buddhist Economic System in Practice: The Rules of State Policy Making of the Ideals Kings Sought a 'Middle Way' Between Right and Left'. American Journal of Economics and Sociology 50, no. 1 (1991): 17-32.

Puntasen, A. 'Buddhist Economics as a New Paradigm towards Happiness'. Society and Economy 29, no. 2 (2007): 181-200. - - - Buddhist Economics: Evolution, Theories and Its Application to Various Economic Subjects. Bangkok: Amarin Press, 2004. Rosser, M. V., J. B. Rosser, and K. Kramer. 'The New Traditional Economy: A New Perspective for Comparative Economics?'. International Journal of Social Economics 26, no. 6 (1999): 763-78.

Rotering, F. Contractionary Revolution: Seizing Power, Shrinking Economies, and Salvaging the Biosphere. No press (licensed under the Creative Commons Attribution-NonCommercial-NoDerivs 3.0 Unported License). 2nd edition, 2013.

Schumacher, E. F. Small is Beautiful. New York: Harper Colophon Books, 1973.

Takatsugu, N. 'The Influence of Confucianism and Buddhism on Life-Innovators in the Japanese Social-Economic Order'.

International Journal of Social Economics 13, no. 3 (1986): 53-63. Weitzman, M., and D. Kruse. 'Profit Sharing and Productivity'. In Paying for Productivity: A Look at the Evidence, edited by A. Blinder, 95-142. Washington: Brookings Institution, 1990. Wilson, R. Economics, Ethics and Religion: Jewish, Christian and Muslim Economic Thought. New York: New York University Press, 1997.

Zadek, S. 'The Practice of Buddhist Economics: Another View'. American Journal of Economics and Sociology 52, no. 4 (1993): 433-45.

Zsolnai, L., ed. Ethical Principles and Economic Transformation-A Buddhist Approach. New York: Springer, 2011. 